\title{
ВИКОРИСТАННЯ ЗАСОБІВ ІНДИВІДУАЛЬНОГО ЗАХИСТУ (МАСОК) У ЗАКЛАДАХ ВИЩОЇ ОСВІТИ: ВІД ТЕОРІЇ ДО ПРАКТИКИ
}

\author{
ВНКЗ лОР «Львівська медична академія імені Андрея Крупинського», м. Львів, Україна
}

Мета: проаналізувати ставлення учасників освітнього процесу в закладах медичної освіти щодо носіння масок та обізнаності їх правильного використання та утилізації згідно з рекомендаціями ВООЗ.

Матеріали і методи. Дослідження проведено у восьми вищих медичних навчальних закладах України 3 використанням теоретичного аналізу та узагальнення даних науково-методичної літератури, дані сучасних досліджень у сорері громадського здоров'я, аналізу анкет анонімного опитування.

Результати. Встановлено, що майже половина респондентів використовує багаторазові маски як засіб профілактики зараження на COVID-19 з економічних міркувань, тоді як 10 \% респондентів взагалі не використовують маски тому, що вважають їх шкідливими, чим збільшують криву зростання інфікування в освітньому середовищі.

Висновки. Для запобігання інтенсивного розповсюдження коронавірусної хвороби (COVID-19) у закладах вищої освіти необхідно чітко дотримуватись міжнародних протоколів і рекомендацій ВООЗ, проводити просвітницьку роботу з молоддю із залученням експертів у галузі громадського здоров'я.

КЛЮчОВІ СЛОВА: коронавірусна хвороба (COVID-19); маска; заклад вищої освіти; студент.

З початком навчального року питання про використання засобів індивідуального захисту (масок) є найактуальнішим чи не у всіх закладах освіти від середніх загальноосвітніх шкіл до закладів вищої освіти. Це складне завдання, яке країни вирішують по-різному. Наприклад, Національний департамент здоров'я США розробив фредеральні рекомендації, але із застереженням, що кожен штат може вирішувати проблему по-своєму. В Україні станом на 30 липня 2020 р. Міністерство охорони здоров'я України (МО3) представило «Тимчасові рекомендації щодо організації протиепідемічних заходів у закладах освіти на період карантину в зв'язку з поширенням коронавірусної хвороби (COVID-19)», де питання використання масок має рекомендований характер, і, відповідно, не всі учасники освітнього процесу розуміють важливість дотримання суворих правил профрілактики розповсюдження інфрекції. Всесвітня організація охорони здоров'я (ВОО3) чітко визначила три головні профрілактичні засоби протидії пандемії на сьогодні: використання засобів індивідуального захисту (маски, респіратори), дотримання соціальної дистанції та гігієна рук [3].

На початку цієї весни двері освітніх закладів у цілому світі зачинились, 1,5 млрд молодих людей залишалися вдома в рамках тотального закриття, з метою захисту людей від нової пандемії. Рішучі заходи вживали в багатьох місцях, різко сповільнюючи поширення SARS-CoV-2, вірусу, що викликає COVID-19. У багатьох країнах були розроблені стратегії боротьби зі стрімким роз(c) Н. В. Костерева, Н. Є. Рудакова, 2020 повсюдженням інфекції. Глобальне поширення COVID-19 на початку 2020 р. суттєво збільшило попит на маски для обличчя у світі, одночасно стимулюючи дослідження щодо їх есрективності та можливості активного використання в умовах навчального процесу. Маски для обличчя - це простий спосіб зменшити передачу коронавірусу та врятувати життя. Згідно з даними Центрів 3 контролю та профрілактики захворювань, доведено, що носіння маски для обличчя в громадських місцях зменшує поширення COVID-19, оскільки ті, хто не має симптомів, можуть поширювати вірус ще до їх появи.

Зараз у всьому світі спостерігають занепокоєння влади різних країн щодо відкриття освітніх закладів та подальшого стрімкого спалаху інфекції через велику кількість студентів та школярів, які захворіли. Спалахи захворювання на COVID-19 цього літа в штатах Вашингтон, Каліфорнія та Міссісіпі дали уявлення про проблеми, з якими стикаються адміністрації навчальних закладів. У серпні газета «Los Angeles Times» повідомила, що всього за кілька днів до початку нового семестру університети по всій території США щосили намагаються стримати спалахи COVID-19, пов'язані з проживанням студентів у гуртожитках (кампусах) і вечірками за межами кампусів у переповнених барах. Університет Північної Кароліни в Чапел-Хілл скасував заняття та заявив, що перейде на дистанційне навчання після повідомлення про 130 підтверджених випадків зараження серед студентів і п'яти серед співробітників за останній тиждень. Тобто, ще до початку навчального року серед студентів, які прибули на 
навчання, почала поширюватися коронавірусна інфрекція [4].

Журнал «Science» розглянув стратегії відновлення освітньої діяльності від Південної Африки до Фінляндії та Ізраїлю і виявив деякі обнадійливі моделі навчання, в яких учні повинні навчатися у невеликих групах, дотримуватися соціальної дистанції та носити маски. Одним із способів боротьби з поширенням коронавірусної інфрекції $€$ дотримання соціальної дистанції. Проте, цей пункт складно запровадити через занадто тісну культуру спілкування у студентському середовищі. Маски можуть допомогти скоротити соціальну дистанцію. Але і до них ставлення у різних країнах неоднакове. Зрозуміло, що студентам незручно носити маски годинами, їм може не вистачити самодисципліни, щоб носити їх постійно, не опускаючи на шию і не вивільняючи ніс [7].

У Китаї, Південній Кореї, Японії та В'єтнамі, де маски вже широко поширені та багато хто носить їх під час сезону грипу, освітні заклади жорстко регламентують носити їх всім учням і вчителям. Китай дозволяє учням знімати маски тільки під час обіду, коли дітей відділяють скляні або пластикові перегородки. В Ізраїлі потрібні маски для дітей старших семи років поза класом, а для дітей четвертого класу і старших - впродовж усього дня. У Німеччині учні носять маски в коридорах і під час відвідування туалету, але можуть знімати їх, коли сидять за своїми (віддаленими) партами.

Чимало вчителів, особливо передпенсійного віку, просто звільняються через страх захворіти на COVID-19. Згідно з опитуваннями шкільних округів США, близько третини співробітників вважають за краще триматися від школи подалі. Особливо після повідомлень про те, що кілька вчителів померли від ускладнень COVID-19 в Швеції, де школи не змінювали кількість учнів у класах і не вводили будь-яких інших протиепідемічних заходів [8].

Мета дослідження: проаналізувати ставлення учасників освітнього процесу в закладах медичної освіти щодо носіння масок та обізнаності їх правильного використання та утилізації згідно з рекомендаціями ВООЗ.

Матеріали і методи. Це дослідження проведено у період із квітня до червня 2020 р. на базі таких освітніх закладів: Львівська медична академія імені Андрея Крупинського, Кам'янський медичний коледж, Чернівецький медичний фраховий коледж, Самбірський медичний коледж, Івано-Франківський національний медичний університет, Медичний коледж Івано-Франківського національного медичного університету, Медичний коледж Буковинського державного медичного університету, ПВНЗ «Медико-Природничий Університет». Всього в опитуванні взяли участь
1354 людей. Для реалізації поставленої мети використовували такі методи дослідження:

1. Теоретичний аналіз та узагальнення даних науково-методичної літератури та всесвітньої інформаційної мережі «Інтернет».

2. Аналіз анкет анонімного опитування, які надали учасники дослідження з різних навчальних закладів освіти України, за допомогою Google Forms.

Результати дослідження та їх обговорення. Аналіз 1354 анкет учасників анонімного опитування показав, що у дослідженні взяли участь 89,8 \% студентів та 10,2 \% викладачів.

На запитання, чи користуєтесь Ви засобами індивідуального захисту від COVID-19 (масками, респіраторами), 98,4 \% дали відповідь «ТАК», $1,6 \%-\ll \mathrm{H} \mid »$.

На запитання, який засіб Ви використовуєте, $44 \%$ респондентів відповіли: «багаторазова маска», 43,6 \% - «одноразова маска» та 12,4 \% «респіратор». Вибір багаторазової маски пов'язаний із ціновою доступністю і зручністю у використанні, можливістю уникати додаткового забруднення довкілля та підкресленням особистості індивідуальним дизайном маски.

На запитання, коли Ви одягаєте індивідуальний засіб захисту, 43,3 \% респондентів відповіли: «кожного разу коли виходжу на вулицю», 37,4 \% «коли заходжу в місця масового скупчення», 10,8 \% - «коли заходжу в приміщення загального користування» і тільки 8,5 \% - «на вимогу закладу».

На запитання, як часто Ви змінюєте одноразову маску, відповідь дали тільки 1310 респондентів. 3 них 46,9 \% дали відповідь, що кожні 2 год після застосування, 26 \% вказали на те, що використовують тільки один раз; 16,1 \% респондентів використовують одноразові маски по декілька разів, 3,7 \% респондентів відповіли, що використовують одноразову маску, допоки вона не порветься.

На запитання, як Ви дезінфікуєте багаторазову маску, 58,1 \% респондентів відповіли, що вони проводять обробку дезінфікуючим засобом (прання та прасування); 19,5\% респондентів здійснюють тільки прання; 10,2 \% опитуваних взагалі не дезінфікують. Більшість респондентів (51,2 \%) після кожного використання багаторазової маски дезінфікують її; 9,6 \% дезінфікують маску один раз у 3 дні та 7,4 \% дезінфрікують їі тільки тоді, коли вона забрудниться.

На запитання, як Ви зберігаєте засіб індивідуального захисту, більше 36,6 \% респондентів відповіли, що зберігають у поліетиленовому пакеті, який може бути або в сумці, або в кишені; $20 \%$ опитаних відповіли, що над цим питанням не думали та зберігають, де їм зручно; більше $20 \%$ зберігають маски в кишені одягу або в сумці поруч із різними речами. 
На запитання, як Ви проводите утилізацію маски, найбільше відповідей було: «викидаю у смітник»; «викидаю, де зручно»; «спалюю»; «у пакеті в сміття»; «розрізаю та викидаю».

Також було задано запитання про використання інших засобів індивідуального захисту. Так, 1166 респондентів додатково використовують антисептичні розчини, 674 опитаних дотримуються соціальної дистанції, 1161 постійно миють руки, 642 людини носять гумові рукавички.

Загалом, термін «маска для обличчя» регулює широкий спектр захисних засобів 3 основною функцією зменшення пропускання частинок або крапель. Передумова захисту від інфікованих людей, які носять маску, проста: носіння маски для обличчя зменшить розповсюдження виділень, викликаних кашлем, чханням або розмовою, що містять віруси. Насправді, останні дослідження показують, що носіння масок для обличчя зменшує поширення COVID-19 на популяційному рівні, а отже, пригнічує зростання кривої епідемії [2]. 3 точки зору державної політики, дефріцит у постачанні хірургічних масок для обличчя та респіраторів N95, а також занепокоєння щодо їх побічних ефректів та дискомфорт при тривалому застосуванні призвели до публічного використання різноманітних засобів, які, як правило, менш обмежувальні (наприклад, домашні бавовняні маски або бандани) [6]. Як показало наше дослідження, майже половина респондентів використовує багаторазові маски як засіб профрілактики зараження на COVID-19. Враховуючи, що у дослідженні взяли участь більш ніж 89,9 \% студентів, економічна складова суттєво збільшує попит на таке користування, також необхідно враховувати можливість підкреслити свою індивідуальність та креативність у середовищі однолітків. Згідно з рекомендаціями дослідницької групи під керівництвом Емми П. Фішер, тканинні маски затримують краплі, які виділяються, коли людина в масці чхає, кашляє або розмовляє. Вони зменшують поширення вірусів, їх легко купити або виготовити, можна прати і знову носити [5].

Аналіз результатів проведеного дослідження показав, що 10 \% респондентів взагалі не використовують маски тому, що вважають їх шкідливими через здатність накопичувати інфекції. I це правда. Маски з тканини, якщо вони не дезінфікуються належним чином, дійсно є переносниками як бактерій, включаючи кишкову паличку, так і вірусів - норовірус і коронавірус. Такі патогени, як бактерії та віруси, можуть жити на тканинній масці до 8-12 год. Тому одноразову маску потрібно змінювати кожні 2-4 год, а тканинну - регулярно прати, дезінфрікувати та добре висушувати та піддавати дії високих температур [1].

Неналежне використання, дезінфекція та утилізація масок призводить до розповсюдження інфрекції, фрормує хибну думку в студентському суспільстві про надійність засобів індивідуального захисту.

ВОО3 у розділі «Запитання та відповіді: Діти та маски», пов'язані з COVID-19, чітко дала відповідь на необхідність використання масок для всіх учасників освітнього процесу:

«У середовищі, де широко поширена передача інфекції, всі дорослі у віці до 60 років, які в цілому мають добре самопочуття, повинні носити тканинні маски, коли вони не можуть забезпечити відстань не менше, ніж 1 м від інших. Це особливо важливо для дорослих, які працюють з дітьми і можуть мати тісний контакт з ними та один 3 одним.

Дорослі у віці 60 років і старше, або які мають супутні основні захворювання, такі як хвороби серця, діабет або рак легень, повинні носити медичну маску через більший ризик серйозно захворіти на COVID-19».

Враховуючи кількість захворювань серед студентів та викладачів закладів освіти, яка стрімко зростає на перших тижнях навчального року, вважаємо за необхідне суворо дотримуватись рекомендацій щодо профрілактики розповсюдження коронавірусної хвороби (COVID-19). На жаль, не до кінця науково доведені негативні моменти при довготривалому використанні масок в освітньому процесі.

За результатами проведеного дослідження нами сорормовано рекомендації відповідно до протоколів ВООЗ та МОЗ України щодо використання масок у навчальному процесі. Також для студентів I курсу, які вступили після 9 класу до Львівської медичної академії імені Андрея Крупинського, запропоновано у першому семестрі навчального року проведення навчальних семінарів-тренінгів на тему використання, зберігання, дезінфекцію та утилізацію масок.

Перспективи подальших досліджень. Подальший розвиток цього напряму буде пов'язаний з дослідженням шкідливих моментів при використанні масок на психоемоційний та фізичний стан студентів і викладачів та вплив на довкілля.

\section{Список літератури}

1. Advice on the use of masks in the context of COVID-19 (WHO Reference Number: WHO/2019-nCov/IPC_Masks/2020.4. World Health Organization. - 2020.

2. COVID-19 Systematic Urgent Review Group Effort (SURGE) study authors, Physical distancing, face masks, and eye protection to prevent person-to-person transmission of SARS-CoV-2 and COVID-19: A systematic review and meta-analysis / D. K. Chu, E. A. Akl, S. Duda [et al.] // Lancet. 2020. - Vol. 395. - P. 1973-1987. DOI:10.1016/S01406736(20)31142-9pmid:32497510. 
3. https://moz.gov.ua/uploads/3/19713-standarti_med_dopomogi_covid_19.pdf

4. https://www.who.int/publications/m/item/key-messages-and-actions-for-covid-19-prevention-and-control-in-schools

5. Low-cost measurement of facemask efficacy for filtering expelled droplets during speech / Emma P. Fischer, Martin C. Fischer, David Grass [et al.] // Science Advances. - 2020. DOI: 10.1126/sciadv.abd3083.

6. Respiratory virus shedding in exhaled breath and efficacy of face masks / N. H. L. Leung, D. K. W. Chu, E. Y. C. Shiu [et al.] // Nat. Med. - 2020. - Vol. 26. - P. 676-680. DOI:10.1038/s41591-020-0843-2pmid:32371934.

7. Couzin-Frankel J. School openings across globe suggest ways to keep coronavirus at bay, despite outbreaks / J. CouzinFrankel, G. Vogel, M. Weiland // Science. - 2020.

8. Ringer J. Which type of face mask is most effective against COVID-19? / J. Ringer. - 2020. - Loma Lind University Health.

\section{References}

1. (2020). Advice on the use of masks in the context of COVID-19 (WHO Reference Number: WHO/2019-nCov/IPC_ Masks/2020.4. World Health Organization.

2. Chu, D.K., Akl, E.A., Duda, S., Solo, K., Yaacoub, S., \& Schünemann H.J. (2020). COVID-19 Systematic Urgent Review Group Effort (SURGE) study authors, Physical distancing, face masks, and eye protection to prevent person-toperson transmission of SARS-CoV-2 and COVID-19: A systematic review and meta-analysis. Lancet, 395, 1973-1987. DOI:10.1016/S0140-6736(20)31142-9pmid:32497510.

3. https://moz.gov.ua/uploads/3/19713-standarti_med_dopomogi_covid_19.pdf

4. https://www.who.int/publications/m/item/key-messages-and-actions-for-covid-19-prevention-and-control-in-schools

5. Fischer, Emma P., Fischer, Martin C., Grass, David, Henrion, Isaac, \& Westman Eric (2020). Low-cost measurement of facemask efficacy for filtering expelled droplets during speech. Science Advances, eabd3083 DOI: 10.1126/sciadv. abd3083.

6. Leung, N.H.L., Chu, D.K.W., Shiu, E.Y.C., Chan, K.-H., McDevitt, J.J., Hau, B.J.P., et al. (2020). Respiratory virus shedding in exhaled breath and efficacy of face masks. Nat. Med. 26, 676-680. DOI:10.1038/s41591-020-0843-2pmid:32371934.

7. Jennifer Couzin-Frankel, Gretchen Vogel, Meagan Weiland (2020). School openings across globe suggest ways to keep coronavirus at bay, despite outbreaks. Science.

8. Ringer, J. (2020). Which type of face mask is most effective against COVID-19? Loma Lind University Health.

\section{USE OF INDIVIDUAL PROTECTION MEANS (MASKS) IN HIGHER EDUCATION INSTITUTIONS: FROM THEORY TO PRACTICE}

N. V. Kostereva, N. Ye. Rudakova

Andrei Krupynskyi Lviv Medical Academy, Lviv, Ukraine

Purpose: to analyze the attitude of participants in the educational process in medical education institutions regarding the wearing of masks and awareness of their proper use and disposal in accordance with WHO recommendations.

Materials and Methods. Research was carried out in eight medical academies

and colleges, we studied data on diseases, recommendations for preventing the spread of infection, analysis of questionnaires of survey participants.

Results. It was found that almost half of the respondents use reusable masks as a means of preventing infection with COVID-19 on economic grounds, while $10 \%$ of respondents do not use masks at all because they consider them harmful, which increases the growth curve of infection in the educational environment.

Conclusions. In order to prevent the intensive spread of coronavirus disease (COVID-19) in higher education institutions, it is necessary to strictly adhere to international protocols and WHO recommendations, to conduct educational work with young people with the involvement of public health experts.

KEY WORDS: coronavirus disease (Covid-19); mask; institution of higher education; student.

Рукопис надійшов до редакції 23.06.2020 p.

\section{Відомості про авторів:}

Костерева Наталія Василівна - викладач кафредри внутрішньої медицини та управління охороною здоров'я ВНКЗ ЛОР «Львівська медична академія імені Андрея Крупинського»; тел.: +38(032) 261-55-42.

Рудакова Наталя Євгенівна - магістр фрізичної реабілітації, викладач кафедри фрізичного та психічного здоров'я ВНКЗ ЛОР «Львівська медична академія імені Андрея Крупинського»; тел.: +38(032) 261-55-42. 